This is an Accepted Manuscript of a paper published by Taylor \& Francis in the American Review of Canadian Studies on October 13 ${ }^{\text {th }}, 2021$. Please cite the published version of this article, which

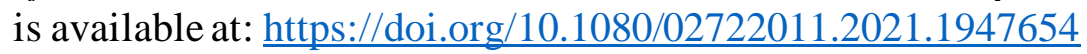

\title{
The Possibility of Multicultural Nationhood
}

\author{
Eric Wilkinson \\ McGill University \\ eric.wilkinson@mcgill.ca
}

\begin{abstract}
In this article, I explain and defend the concept of multicultural nationhood. Multicultural nationhood accounts for how a nation can have a cohesive identity despite being internally diverse. In Canada, the challenge of nation-building despite the country's diversity has prompted reflection on how to conceive of the national identity. The two most influential theories of multiculturalism to come from Canada, those of Charles Taylor and Will Kymlicka, emerged through consideration of Canada's diversity, particularly the place of Québécois, Indigenous peoples, and immigrants in society. Ibegin by synthesizing Taylor's and Kymlicka's theories. Ithen propose a new subjective definition of nation, wherein the character of a nation is determined by how its members conceive of themselves. Once these concepts are explained, they are combined in an account of multicultural nationhood. Multicultural nationhood involves the cultivation of a national identity wherein various cultural groups are recognized as constitutive of the nation.
\end{abstract}

Canada's national identity has been a longstanding preoccupation in Canadian philosophy. The internal diversity of Canadian society has prompted reflection on what Canadian nationalism is, and what it can or should be. Multiculturalism is often said to be a defining feature of the nation. But what does it mean to say that a nation is multicultural, or possesses a multicultural nationalism? To understand what multicultural nationhood is, one must understand its two constituent concepts: multiculturalism and nation. In this article, I synthesize two views of multiculturalism from Canada, those of Charles Taylor and Will Kymlicka, which define multiculturalism in terms of the ethical value of recognition. I then propose and argue in favor of a subjective definition of nation, which asserts that the character of the nation is determined by how its members conceive of themselves. Once these concepts are explained, they can be combined to understand multicultural 
nationhood. A multicultural nation is one in which cultural diversity is thought to be constitutive of the nation. The different cultural communities are recognized as being part of the supervening nation. This account offers a conceptual framework for understanding Canada's national identity.

\section{MULTICULTURALISM}

\section{Charles Taylor's Politics of Recognition}

The keystone of Taylor's political philosophy is the dialogical nature of individual identity. He writes that we "define our identity always in dialogue with, sometimes in struggle against, the things our significant others want to see in us" $(1992,33)$. Personal identity is developed through conversation with both other individuals and group identities. This insight is Hegelian. For Hegel,

participation in a common identity constituted by civil society (Sittlichkeit) is necessary for human flourishing while the abstract, atomistic identities (Moralität) that characterize liberal societies are insufficient (Sibley 2008, 179). For Taylor, "The doctrine of Sittlichkeit is that morality reaches its completion in a community ... Because the realization of the Idea requires that man be part of a larger life in a society, moral life reaches its highest realization in Sittlichkeit" $(1975,377)$. This Hegelian principle permeates Taylor's philosophy, informing his criticism of atomistic liberalism, his view of the malaise of modernity, and the idea of recognition in his theory of multiculturalism.

An early concern in Taylor's writings is the "atomistic" nature of liberal political thought. ${ }^{1}$ In The Pattern of Politics, he critiques liberalism, and in particular market economics, individualist culture, and American influences over Canadian politics (1970, 3). This early work is an attack on capitalist economics that criticizes "the corporate system" for creating economic inequality $(1970,17)$. What is distinctive is Taylor's analysis of alienation and the loss of collective meaning. The conception people have of themselves in capitalist society as atomistic individuals 
subverts their capacity for class identification and collective action that could improve their material situation.

Instead of collective identities, consumer goods become the standard for well-being, and individuals experience "privatization," a "tendency for people to find meaning for their lives on their own outside of the collectively celebrated public meanings" (1970, 57). This "privatization" of meaning in modern society is Taylor's distinct contribution. The loss of common purposes is a symptom of privatization and deprives the public realm of the resources to pursue collective goals. A society unable to pursue collective goals cannot meet the socio-economic conditions necessary for dignity. Taylor derides America as one society where the dominant ethos of private meaning inhibits collective action $(1970,106)$. Conversely, he believes Canada retains a more communal culture, which facilitates collective goals like the Canadian Pacific Railway, or public healthcare.

This conception of the privatization of meaning found in The Pattern of Politics anticipates Taylor's later work on identity in Sources of Self, The Malaise of Modernity, and A Secular Age. In the second of these, Taylor identifies three "malaises" associated with modernity: individualism, instrumental reason, and the loss of freedom (1991, 264; Taylor 1989a; Taylor 2007). Taken together, the malaises associated with individualism and instrumental reason correspond to the privatization of meaning. In modern society, individuals choosing their own lives for themselves is said to have led to the loss of "larger social and cosmic horizons of action" since "[p]eople lost the broader vision because they focused on their individual lives" (1991, 261). Instrumental reason is the "rationality we draw on when we calculate the most economical application of means to a given end" $(1991,262)$. As people become disenchanted with the social meanings that connected their action to a moral purpose, they turn to instrumental reasoning. Modernity thus created 
societies characterized by the Hegelian Moralität: people have atomistic identities, and their actions are detached from the good of the social whole.

The third malaise, the loss of freedom, is a consequence of the other two. People in modern society lack the freedom to choose to pursue collective goods that might otherwise be had. Taylor gives the examples of combating climate change or developing good public transport $(1991,264)$. While his earlier work focused on economic inequality, the diagnosis of the problem is the same. Liberal modernity has alienated people from group identities and thereby restricted their freedom.

The alienation that arises in modern society indicates a problem with negative definitions of freedom developed by classical liberal philosophers. Whereas John Locke and Thomas Hobbes conceive of freedom as lack of constraint, Taylor argues that freedom is a social and moral good. For Taylor, rights presuppose human capacities that can only be developed in a society, hence the primacy of rights puts the cart before the horse. While critiquing Hobbes' idea of negative freedom, Taylor outlines the social conditions of freedom: "freedom requires a certain understanding of self, one in which the aspirations to autonomy and self-direction become conceivable; and second, that self-understanding ... is always partly defined in conversation with others or through the common understanding which underlies the practices of our society" $(1985 \mathrm{~b}, 198)$. This concept of freedom is not just social, but also moral, in that individuals cannot freely pursue just any course of action.

Proponents of negative freedom mistakenly sever freedom from ethics by refusing to make qualitative distinctions between different ways of living, leaving the individual as the only judge of what is best for themselves (Bickerton, Brooks, and Gagnon 2006, 93). Taylor instead adopts a conception of positive freedom associated with Kant: "If to be free is to follow the moral law, and to act morally is to see that the maxim of my action could be willed universally, then freedom requires that I understand as myself as standing under a law that applies as well to others" (1985c, 
326). Individual freedom can only be maintained in a society of a certain kind. We have seen that there are economic conditions necessary for freedom, but Taylor argues there are cultural ones as well.

What are the consequences of these insights for multiculturalism? Individual identities are dialogical and having sources of communal association that one's identity evolves in relation to is necessary for freedom. The existence of cultural identities, through which individuals dialogically develop their personal identities, is valuable. For instance, a francophone Quebecer can shape their self in relation to the Québécois identity, which provides both a horizon of meaning and basis for collective action. The refusal of others to recognize the validity of a group identity central to one's self-understanding will inflict harm on that person. Denial of recognition "can erode the common understanding of equal participation on which a functioning liberal democracy crucially depends" (Taylor 1993, 190). Misrecognition causes harm since "projection of an inferior or demeaning image on another can actually distort and oppress" (Taylor 1992, 36). Recognition is then owed to cultural groups, as its denial can inhibit member's freedom by undermining the group identity central to their self.

The predominant collective identity to emerge with modernity is the nation. Taylor views rising "nationalism, the singling out of linguistic nationality as the paradigm pole of self-identity" as "part of the modern drive to emancipation" $(1993,47)$. Nations are a collective identity that can provide the conditions necessary for freedom. Nonetheless, recognition of national identities does not necessitate national sovereignty. A viable multinational state can be established if recognition is given to its component nations, with enough opportunity for cultural expression and cultivation. The requirements different cultural groups have in terms of recognition will differ according to the nature of those groups. An immigrant cultural community, like Italian-Canadians, may not require 
the same kind of recognition as minority nations like the Québécois or Indigenous groups. Taylor addresses this through "deep diversity," which seeks cohesion by maintaining that "a plurality of ways of belonging be acknowledged and accepted" $(1993,183)$. The Canadian nation supervenes on the cultures within it and belonging to any of these group identities is a way of being Canadian.

\section{Will Kymlicka’s Multicultural Citizenship}

An early and influential version of Kymlicka's theory appears in MulticulturalCitizenship. There he begins with a distinction between two categories of cultural diversity found in a society. ${ }^{2}$ First, there are national minorities that arise "from the incorporation of previously self-governing, territorially concentrated cultures into a larger state" $(1995,10)$. These groups wish to remain as distinct societies alongside the majority culture, and thus demand autonomy or self-government to ensure this survival. A second source of cultural diversity is immigration. Immigrants often form "ethnic groups" in society, but "want to integrate into the larger society, and to be accepted into

it" $(1995,11)$. These latter cultural groups demand recognition of their ethnic identities, but do not require the same autonomy as national minorities. Kymlicka offers examples from several societies to illustrate this distinction, but the most detailed case he gives is that of Canada, which "involved the federation of three distinct national groups (English, French, and Aboriginal)" $(1995,12)$. His discussion of immigration and immigrant ethnic groups likewise focuses on the Canadian context.

The rights a cultural minority correspond to whether it is a national minority or an immigrant ethnic group. Kymlicka notes three types of group-specific rights used to accommodate national and ethnic diversity: self-government rights, poly-ethnic rights, and special representation rights (1995, 27-31). As nations often demand some form of political autonomy, self-government rights secure the autonomy needed for cultural development. Federalism is one arrangement that can offer autonomy to a national minority, and Kymlicka gives the example of Québec in Canada. 
Canadian federalism allows the devolution of powers like education to the province of Québec that enable the cultural cultivation desired by the Québécois. Poly-ethnic rights instead correspond to immigrant ethnic groups; these are measures that enable ethnic groups and religious minorities to express their culture while participating in society. Kymlicka offers the example of the exemption that Sikh Canadians in law enforcement have to headdress requirements. A final category of rights, special representation rights, are germane to both national minorities and ethnic groups. These are aimed at ensuring the representation of groups, particularly marginalized ones, in centers of power.

Kymlicka's argument for minority rights depends on the relationship between individual freedom and cultural membership. The cultures relevant to freedom are societal cultures, which provide "members with meaningful ways of life across the full range of human activities, including social, education, religious, recreational, and economic life" (1995, 76). A societal culture has its own internal institutions, practices, shared traditions, and conventions. The survival of a culture in modernity depends on whether it is a societal culture, since maintaining a culture requires access to education and other institutions. Here the distinction between national minorities and immigrant ethic groups becomes crucial: the national minorities incorporated into a state possess a complete and meaningful way of life, while immigrants arrive expecting to integrate into their new country. The fragmentary nature of the societal cultures associated with "ethnic groups" explains why these groups do not demand autonomy, and why they are not owed self-government rights. National minorities have the resources to offer complete, meaningful ways of life if granted their autonomy. In addition to articulating the relationship between culture and freedom, Kymlicka outlines three other arguments in favor of group-differentiated rights, which are based on equality, history, and the value of diversity. The equality argument maintains that because some groups are "unfairly disadvantaged in the cultural marketplace," supportive measures ensure their interests receive 
equal consideration (1995, 14). For instance, a national minority's societal culture may be vulnerable because of the economic or political decisions of the majority. Restrictions on the sale of land are necessary in Canadian Indigenous communities to ensure the retention of the resources necessary for cultural survival $(1995,110)$. Whereas the majority culture always has their interests attended to, differentiated rights are necessary to ensure national minorities receive equal attention.

The second argument is based on historical agreements. Kymlicka has in mind Indigenous treaty rights in Canada $(1995,117)$. Historical agreements can confer group-differentiated rights that are the condition of some political arrangement. Indigenous Canadians often enjoy hunting or fishing rights based on historic treaties that permit settlement on previously Indigenous territory. While historical agreements are one source of group-differentiated rights, Kymlicka warns against giving them too much weight. Treaties can be disputed, may not meet the contemporary needs of a community, and some groups might not have treaties — as is the case with Indigenous Canadians.

The final argument appeals to the value of cultural diversity. Cultural diversity can enrich and increase the cultural options available. This argument appeals to the interests of the majority culture, instead of considerations of fairness or obligation, like the prior two arguments. Even the majority have their horizons of choice enriched by living in a multicultural society. However, one should not give inordinate weight to this argument, since it only supports diversity itself, and says nothing about what is owed to existing national minorities in a society (Kymlicka 1995, 121). This argument should be understood as an auxiliary benefit and not the main basis for groupdifferentiated rights.

Although the most influential form of Kymlicka's arguments for multiculturalism are those found in Multicultural Citizenship, his follow-up work on this subject focuses more directly on the question of nation-building. With the onset of modernity, many states engaged in nation-building 
projects on the behalf of the majority culture, which placed certain demands on minority cultures to assimilate by adopting a majority language, practices, or institutions. In many cases, societal minorities face the decision of engaging in a competing nation-building project or being assimilated into the dominant culture $(2001,27)$. For Kymlicka, it is unsurprising that when faced with this decision many decide to cultivate a new minority nationalism (2001, 2). In recent history, liberal democracies have shifted toward granting minority rights, and this is more successful than previous efforts to build nations through conformity. Multicultural policies facilitate a more ethical kind of nation-building, where minorities are given room enough to breath. Kymlicka is therefore offering a theory of "permissible forms of nation-building within liberal democracies" $(2001,29)$.

As with Taylor, the theory of multiculturalism presented by Kymlicka is a normative one. Cultural diversity is good because cultures offer "contexts of choice" that provide meaningful options against which people can frame, revise, and pursue their goals (Kymlicka 1995, 89). Furthermore, one's own culture is valuable since it provides an "anchor for their self-identification and the safety of effortless secure belonging" $(1995,89)$. Cultures thus facilitate freedom by offering options one is free to choose among. Multiculturalism denotes the group-differentiated rights used to secure the primary good of culture. Kymlicka differs from Taylor by basing his theory in a more "liberal" view of individual freedom. Whereas Taylor's idea of the moral whole (Sittlichkeit) leads him to view freedom as only possible in the context of a community, Kymlicka argues that rights-based liberalism is compatible with this social thesis $(1989,95)$. For Kymlicka, a society with a liberal normative framework is not necessarily so "atomistic" that it cannot justify multiculturalism.

\section{Comparison and Synthesis}


The chief difference between Taylor and Kymlicka has been framed in terms of the former being a "communitarian" and the latter a "liberal" theorist of multiculturalism (O'Neill 1999, 222). According to this distinction, a liberal prioritizes individuals and their goods and rights over those of society, whereas a communitarian acknowledges the goods and rights that attach to communities. Kymlicka is often characterized as a liberal rather than a communitarian since his justification for multiculturalism is that culture is valuable for offering individuals meaningful contexts of choice. Conversely, Taylor holds that cultures are valuable apart from their extrinsic good to individuals.

Within the liberal-communitarian debate there are two distinct threads that are frequently conflated, that of ontology and advocacy (Taylor 1989b, 159). The ontological aspect of the debate concerns whether only individuals or both individuals and collectives can be intrinsically valuable. This can be distinguished from the question of advocacy, which is a matter of the moral standards or policies an author endorses. The ontological position one adopts on whether collectives possess intrinsic value tends to inform one's views on advocacy, but authors can differ on ontology while advocating for the same ethical conclusions. Although these commitments have implications for how and when collective rights override individual rights (Taylor 1994, 260), for present purposes it is enough to note that both Taylor and Kymlicka advocate the ethical importance of recognition.

There are some differences in how Taylor and Kymlicka argue for the value of recognition related to their ontological views. As noted above, Taylor cites the dialogical nature of indi vidual identity and agues for recognition directly from how its denial inflicts harm (1992, 36). Kymlicka instead argues that the exercise of freedom requires a range of options to choose from, and that cultures are "contexts of choice" that provide options regarding how to live one's life $(1995,89)$. The trouble with Kymlicka's argument is that it does not explain why one requires access to their 
own culture in order to have an adequate range of options. If cultures are only extrinsically valuable for facilitating choice, then it does not matter which culture offers the choice. This means that the loss of own's own culture does not undermine that person's freedom if they have other options. Kymlicka's response is to follow Taylor in arguing that personal identity formation is dialogical (1995, 90), and that denial of access to one's own culture thus causes harm. A dialogical conception of personal identity is thus used by both authors to justify their ethical commitment to recognition.

Having outlined both Taylor and Kymlicka's views, we are now able to synthesize them to understand multiculturalism. Multiculturalism involves an ethical commitment to offer recognition to the cultural groups in society. Recognition is mutual respect for the cultural features embedded in individuals' identities and can require the accommodation of these cultural practices through group-differentiated rights and other measures. This provision of recognition is in turn necessary since it offers a horizon of meaning and basis for collective action necessary for positive freedom.

\section{Criticism of Recognition}

Theories of multiculturalism based on recognition have been subject to criticism, and while there is not space to exhaustively answer those criticisms here, it is worth addressing some of them. One prominent critique is that the politics of recognition insufficiently addresses the structural and economic bases of social oppression (Coulthard 2014, 34). Those critical of capitalism ${ }^{3}$ allege that liberal multiculturalism does not address the economic forces behind misrecognition. Similarly, liberal egalitarians argue that the "culturalization" of the problem has led to neglect of the causes

of group disadvantage (Barry 2013,305), such as disparities in education, employment, or housing.

There is nothing inconsistent about acknowledging both problems of misrecognition and redistribution. As Taylor argues, cultural recognition is one necessary condition for freedom, and 
he outlines the economic conditions necessary for freedom in The Pattern of Politics. The critics are right to observe that the economic and cultural issues are intertwined, but addressing economic disparities through wealth redistribution or group-differentiated social programs is consistent with liberal multiculturalism. If the criticism is that multiculturalism does not undermine capitalism, then it unacceptably reduces cultural issues to those of class. As forms of misrecognition can occur outside capitalist contexts, the reduction of all cultural issues to economic injustice is unwarranted.

Another criticism is that theories of multiculturalism understand cultures as determinate, bounded, and homogenous, but they are fluid, overlapping, and heterogenous (Patten 2014, 38). Essentializing cultures by treating them as monolithic is empirically and ethically wrongheaded. No culture is internally homogenous and approaching groups as though they are, leads to a failure to recognize the diversity that is constitutive of the community. However, the other horn of the dilemma is that a non-essentializing view of cultural groups is thought to deprive multiculturalism of the means to make normative claims about groups' needs. If cultures are internally diverse one cannot identify them as discrete wholes to which recognition or group-differentiated rights can be allocated. An accurate view of culture thus undermines the normative project of multiculturalism.

A defender of multiculturalism must provide a non-essentialist conception of culture that can support multiculturalism's normative project. This definition cannot hold that beliefs, values, practices, or institutions are definitive of a culture (Patten 2014, 50). To do so reifies certain characteristics as constitutive of the culture and precludes both the possibility of internal diversity and change. One account of culture that avoids this is based on continuity. If culture is understood as continuity of socialization, internal diversity and change is possible. For instance, Québec's society changed during the Quiet Revolution, but those who enacted this were socialized by a previous generation of francophone Quebecers. Continuity of cultural transmission thus remained 
despite the changes in institutions and practices. There are then plausible accounts of culture that are non-essentialist in the way necessary for a theory of multiculturalism, and by extension multicultural nationhood.

\section{NATIONHOOD}

There are two prevailing accounts of nation in nationalism studies: objective and subjective definitions. ${ }^{4}$ In this section I critique both the objective and subjective definitions of nation, and in the process, I identify two desiderata that must be satisfied by any adequate definition of nation. The definition must not exclude apparent examples of existing nations, and it must also be capable of distinguishing nations from other types of human communities. After establishing these criteria, I propose a new definition that satisfies them and helps us to understand multicultural nationhood.

\section{Objective Definitions}

Objective definitions of nation define nations in terms of certain "objective" characteristics they possess. The objective markers used to designate nations on these definitions typically include religion, ethnicity, language, territory, history or culture (Hobsbawm 1990, 5; Özkırımlı 2005, 15). This approach is exemplified by Anthony Smith for whom a nation is "a named human population sharing a historic territory, common myths and historical memories, a mass, public culture, a common economy and common legal rights and duties for all members" (2005, 24). For Smith, no one of these characteristics is sufficient to be a nation; they all must be possessed in conjunction. Objective definitions are in some ways intuitively compelling because they try to define the nation through reference to the most prominent features of existing nations. Most of the communities that theorists hope to classify, such as the Russian or French nation, seem to have these characteristics.

The problem with objective definitions is that on closer examination the objective markers fail to accurately delineate the boundaries of apparent nations. Ernest Renan raised this critique in 
his seminal essay What Is A Nation? There he rejects dynasty, race, language, religion, geography, and community of interest as potential bases for nationhood (1990, 4). Most of these criteria span the boundaries of different nations, and thus cannot be used to distinguish them from one another. For instance, many nations have members who speak the same language or practice the same faith as members of another nation. Conversely, many apparent nations have members within them that speak different languages or practice different religions despite sharing the same national identity. Race is similarly not a suitable principle for grounding nationhood since all nations are multiracial and racial distinctions transcend national boundaries. As Renan remarks: "A Frenchman is neither a Gaul, nor a Frank, nor a Burgundian," and "[t]he truth is there is no pure race," thus he concludes that "to make politics depend on ethnographic analysis is to surrender it to a chimera" (Renan 1990, 5-6). In sum, no objective marker accurately tracks the boundaries of the nations they hope to classify.

A further problem faced by Smith's objective definition is the need to differentiate nations from other types of community. Consider his definition of an ethnic community: "a named human population with myths of common ancestry, shared historical memories and one or more common elements of culture, including association with a homeland, and some degree of solidarity" (2005, 25 , emphasis in original). The objective markers used to designate an ethnic community overlap significantly with those that define a nation. In particular, both include a territory, historical memory, and common culture. For Smith, this overlap draws attention to the close relationship that often exists between ethnicity and nationalism. However, as Renan illustrates, national communities cannot be reduced to ethnic ones. Thus, any adequate definition must also differentiate nations from other types of community. In addition to being too narrow, objective 
definitions also run the risk of becoming too broad when the objective markers used to define nations are shared with other kinds of collectives or identities.

\section{Subjective Definitions}

A subjective definition of nation defines the nation in terms of the subjective commitment of the members of the nation, rather than any objective markers. An early subjective definition was proposed by Renan, for whom a nation is a twofold "spiritual principle" that consists of a common memory of a shared past, and the people's willingness to continue to live together $(1990,8)$. Renan emphasizes that nations have a shared memory. As a memory, the collective recollection of events does not need to be strictly factual, and he asserts that it is normally selective. Forgetting the past is often a crucial part of forming a cohesive national consciousness. Renan provides the example of how French citizens have mostly forgotten the details of the St. Bartholomew's Day Massacre, where thousands of Protestant Huguenots were killed by Catholics (Renan 1990, 2). In Canada, national forgetfulness can apply to events like the conquest of New France by the British, or the Residential Schools that victimized Indigenous youth through forced assimilation. Remembering these events disrupts the process of national mythologizing, while forgetting facilitates national consciousness.

The second part of Renan's "spiritual principle" is the willingness of the people to continue to live and work alongside each other. He characterizes this as a "daily plebiscite" $(1990,8)$, where people identify with and live together, instead of disavowing their common society and going their own way. A people might possess a common historical memory but become unwilling to continue living together because of political, social, or economic events. For instance, the thirteen American colonies that declared and subsequently fought for their independence in 1776 shared a view of their heritage that largely aligned with the British, yet economic and political issues were capable 
of undermining this solidarity. The reverse is also possible: political circumstances can forge new national communities from people with different historic memories of their heritage. The Canadian identity that gradually emerged following Confederation is described as a "political nationality" by W.L. Morton for this reason $(1962,116)$. Although French and English Canada did not have a common memory, they committed to living and working together to ensure their mutual survival.

The main issue with Renan's subjective definition is that it cannot distinguish nations from other kinds of communities or collective identities. Recall the above criticism of Smith's definition of nation for overlapping with his definition of ethnie. The foremost threat to subjective definitions is that they overlap with definitions of other kinds of communities. Many religions also possess a shared historic memory, and a willingness among their members to live and work together. The same can be said for an ethnic community, or even a curling club. An adequate definition must analytically distinguish nations from other kinds of groups by explaining what differentiates them.

Benedict Anderson attempts to overcome this issue by specifying what kind of subjectively constituted community nations are as opposed to others. Anderson describes nations as imagined communities, imagined as both sovereign and limited (2016,5-6). Nations imagine themselves as sovereign as the notion "was born in an age where Enlightenment and Revolution were destroying the legitimacy of the divinely-ordained hierarchical dynastic realm" $(2016,7)$. Anderson connects the rise of nations with industrialization, particularly the advent of print capitalism in Europe. With dynastic and religious authority waning in the modern period, nations became the reference point for state sovereignty. Nations are necessarily imagined as limited because all nations have "finite, if elastic, boundaries" $(2016,7)$, with all nations viewing themselves as a specific subset of humanity. 
There is reason to doubt that the nation must necessarily be imagined along either of these lines. First, there are apparent nations that do not conceive of themselves as having to be sovereign. Some states, like the United Kingdom, contain multiple nations that are mostly content to share sovereignty. Although there are nationalist movements within the UK that pursue sovereignty for their nation, there are people within each of these nations that value their national identity while preferring to remain within a system that limits national sovereignty. Some nationalist movements are even committed to seeing themselves as part of a larger sovereign entity. The French-Canadian nationalism of Henri Bourassa claimed French-Canada was inextricably part of a larger Canadian nation (Bourassa 1969, 123), and many contemporary Québécois federalists take a similar stance.

Second, there have also existed nations that do not imagine themselves as limited. The French and American Revolutions were based on principles that were said to be universal and thus germane to all of humanity. Yet, the Americans and French were specific communities imagining themselves as defined by their conviction in these universal principles. There is therefore no good reason to suppose that national communities must necessarily imagine themselves as sovereign or limited because there are examples of apparent nations that have not imagined themselves as such.

Without the stipulation that the nation imagines itself as limited and sovereign, Anderson's definition contains nothing to differentiate nations from other imagined communities. Like Renan, Anderson falls prey to the chief flaw of subjective definitions in general: they cannot distinguish nations from other types of communities. Even before Anderson's view is shorn of the requirement that nations be imagined as sovereign and limited, it cannot exclude all non-national communities. Religious, linguistic, and ethnic groups are also imagined communities that could come to imagine themselves as sovereign and limited. A defender of Anderson might argue that this process would be tantamount to becoming a nation. However, this threatens to attribute nationhood to any human 
community that has pursued sovereignty. As there are non-national communities that have aspired to become sovereign, Anderson's definition should be rejected, like Renan's, for being too broad.

\section{A New Definition}

In the process of refuting objective and subjective accounts of nation we have developed a short list of desiderata for any adequate definition of nation. First, the definition must be able to accommodate most if not all apparent nations. The objective definitions run a foul of this requirement as there are always instances of nations that do not have certain objective markers described as necessary for nationhood. Second, there is the requirement that the definition differentiate nations from other kinds of communities. Smith's objective definition also did not meet this criterion, but it presents a greater challenge for subjective definitions of nation si nce subjective identification is characteristic of many types of human communities. Any adequate definition of nation must then satisfy the two conflicting imperatives of accommodating examples

of apparent nations while also distinguishing nations from other kinds of groups. The definition I present here meets this standard.

A nation is an inter-subjectively constituted community with no necessary content. To hold that nations are inter-subjectively constituted adopts the basic conceit of all subjective definitions: the nature of a nation is determined by the collective self-conception of its members. For instance, Québec is part of the Canadian nation insofar as Canadians, including those within Québec, view the province as part of the nation. Similarly, a Canadian nation could be said to characteristically uphold a certain value or principle, like a belief in responsible government, insofar as Canadians believe in such a principle and take it to be characteristic of Canada. This aspect of the definition is basically similar to other subjective definitions like those of Renan or Anderson. However, the national consciousness is not homogenous, as members of the nation frequently disagree over what 
the nation is or should be and challenge their fellow nationals in an attempt to (re)define the nation. Acknowledging that nations are inter-subjectively constituted is to admit that they are an inherently contested identity. All that is required to be a member of a nation is to identify with the nation and to participate, even passively, in this internal struggle over how the community characterizes itself.

The claim that nations have no necessary content draws a distinction between the necessary and particular content of human communities. Necessary content refers to characteristics without which a community would not be the kind of community that it is. For instance, common descent, or at least a myth of common descent, is a necessary characteristic of an ethnic group. If an ethnic group were not defined in terms of its members having some common ancestry, it would cease to be an ethnic group. All communities have some necessary content without which they cease to be the kind of community that they are, except nations. Necessary content is different from particular content, which encapsulates the characteristics of a group that are irrelevant to its definitionally being a specific sort of community. All communities have particular content, including nations. A community might have a million members, or a territory of $3,000,000 \mathrm{~km}^{2}$, but these facts have no bearing on whether it is a nation. Particular content is just the descriptive character of a community.

The combination of inter-subjectivity and a lack of necessary content enables this account to surmount the objections posed against other definitions. Recall that the first of my desiderata stipulates that an adequate definition must account for all appare nt nations. The claim that nations are inter-subjective readily meets this challenge. The differences between specific nations can be explained in terms of the nation's members differing in their collective self-conception. The nation might imagine itself to have any number of objective markers, or lacking some, depending on how national consciousness is cultivated. As there are no principled limits on how a national community can conceive of itself, there are no exceptional nations that fall outside of this definition's scope. 
The second desideratum requires that an adequate definition distinguish nations from other types of communities. This is the requirement that is often fatal for subjective definitions of nation like that proposed here. However, my view avoids this dilemma by distinguishing nations through their lack of necessary content. No other kind of community has the malleability of nations; nations are the most "abstract" form of community and it is this degree of abstraction that separates them from other types of community. All other communities have necessary content without which they would cease to be the kind of community that they are. The only thing that a nation can "lose" that would cause it to cease to be a nation is its lack of necessary content, possibly by calcifying into a different kind of community, like an ethnic group. This definition thus satisfies my two desiderata by encapsulating all apparent nations and differentiating nations from other types of communities.

\section{MULTICULTURAL NATIONHOOD}

Having outlined both the concepts of multiculturalism and nation, we are now in a position to assess the relationship of multiculturalism to nationhood. ${ }^{5}$ Part of the debate over multicultural nationalism centers on the issue of whether its two components are compatible. "Multiculturalism" is used to refer to three related things: sociological diversity, public policy, and an ethical principle. First, one might observe that Canada is factually diverse, as it includes people of many ethnicities, religions, and backgrounds, etc., and thus conclude that it is multicultural in a descriptive sense. A second use of the term refers to public policies designed to address the fact of cultural diversity. Official multiculturalism, as outlined in the Canadian Multiculturalism Act, is multiculturalism as policy. The final use of the term, and that most relevant to the issue of multicultural nationhood, is multiculturalism as an ideal or principle to be upheld — a normative stance taken toward the facts

of diversity. As we have seen, the theories proposed by Taylor and Kymlicka fall into this third category of expressing ethical principles meant to be applied when dealing with diverse societies. 
This clarification enables us to dispense with one common argument against multicultural nationhood. Multiculturalism is sometimes characterized as a sort of moral relativism that holds that there are no universal ethical principles that transcend one's cultural context (Bibby 1990, 9). Insofar as the nation depends for its existence on a commitment among its members to some stock of common values (Kohn 1961, 10), cultural relativism is thought to undermine this foundation. However, the meta-ethical thesis that moral truth is culturally relative is simply incompatible with the assertion that "multiculturalism" designates a set of ethical principles that should guide how a nation addresses its internal diversity. The claim that we ought to extend recognition to minorities in society lest we harm them through misrecognition is the assertion of a specific ethical principle that is not relative to culture. Therefore, contrary to the accusations of its critics, the adoption of multiculturalism does not entail moral relativism since it consists of endorsement of a moral stance.

However, there is a more fundamental sense in which multicultural nationhood is believed to be contradictory. Critics of multiculturalism argue that recognition of diversity is antithetical to binding people together into a cohesive national identity (Bibby 1990, 95; Bissoondath 2002, 71). Gerald Kernerman describes the issue thusly: "multiculturalism (as an embrace of diversity) and nationalism (a quest for unity and identity) are often depicted as contradictory ideas, reflecting ... age-old oppositions as the one and the many, unity and diversity, particularism and universalism" (2005, 5). While nations are cohesive and unified, multiculturalism understands society as diverse. Parsing this contradiction reveals that it rests on an objective definition of nation in which people are unified by a shared characteristic, such that the recognition of diversity precludes nationhood. However, objective definitions of nation have already been shown to be hopelessly faulty. Instead, under the subjective definition of nation I defended, the character of a nation is determined by how those who identify as members view themselves. Insofar as the nation's members commit 
themselves to an ideal, it is then one of the nation's ideals. For this reason, nations are "horizontal" forms of social organization, since their character is determined by an act of collective imagining (Taylor 1995, 181). The conceptual limits of a national identity are those of the members' imaginations.

A nation can conceive of itself as committed to valuing recognition as an ethical principle; hence a nation can be multicultural in the sense of being committed to the ideal of multiculturalism. In the same sense, a nation can commit itself to any particular value, be it the value of democracy or liberty. However, recognition plays a larger role in the process of national imagining than other ethical principles or commitments the nation might take on. That is, a commitment to recognition is a commitment to a principle that bears on the question of how the nation should imagine itself. If the members of the nation acknowledge their duty to provide recognition to the cultural groups within the nation, they must imagine the nation such that there are several valid ways of belonging. For instance, Canadians must conceive of the nation as representing a common pole of identity for English, French, Indigenous, and immigrant groups, or else those they exclude are denied the space to see themselves as part of the common national community. Recognition is not just a principle a nation can imagine itself as endorsing, but one with implications for how it should imagine itself.

Recognition thus plays the important role of not only ensuring that the national whole treats the cultural minorities within it fairly, but also provides those cultural minorities the space to see themselves as part of the national whole. The price of granting insufficient recognition to minority cultures is that they disassociate themselves from the nation - they cease to see themselves as part of the national whole since they can no longer see their cultural identity as part of the nation. This disassociation is evident in Taylor's example of Canada's failure as a nation to recognize Québec as a distinct society $(1992,36)$. The Meech Lake Accord was meant to provide the Québécois with 
the recognition necessary for them to imagine themselves as part of a larger Canadian community. As the rejection of the Accord constituted denial of this recognition, it should be unsurprising that the Accord's failure boosted Québec's separatist movement. As Kymlicka argues, the emergence of minority nationalism is a natural response to receiving insufficient recognition from the majority nation $(2001,2)$. If a plurality of ways of belonging to the larger nation are not permitted, then the supervening national identity will fracture along the fault lines where recognition is withheld.

Although Québécois nationalism has subsided—for the moment—-there remain significant national fault lines in Canada. In particular, Indigenous nationalisms that disassociate from a larger Canadian nation have grown in prominence (Alfred 2009, 43). The case of Indigenous peoples in Canada illustrates that recognition cannot be limited to a willingness on the behalf of the majority to imagine the national community as including minority groups if it is to succeed in holding the nation together. Although necessary, this willingness of the majority culture to recognize that other cultural groups can authentically belong to the nation does not itself ensure that said minority has the cultural breathing room within the national community to see themselves as part of the nation.

Recognition is not then enough if understood as merely a disposition taken toward other cultures within the nation. Affirming the validity of a diverse range of cultures internal to a nation is worth little if those cultures are not provided what they need for their cultural expression. Here Kymlicka's group-differentiated rights substantiates recognition by providing cultural minorities with the means for expression. As societal cultures, Indigenous communities demand and require more autonomy than immigrant ethnic cultures to cultivate and preserve their cult ural identities. Consequently, recognition demands that Indigenous self-government not be impeded where it is desired. Contrary the fear that this will distance Indigenous peoples from the Canadian nation, self-government can facilitate the identification of Indigenous peoples with Canada by revealing 
how their identity is compatible with participation in a broader Canadian nationality. An analogy may be drawn between this and the devolution of federal powers to Québec, which similarly provides Quebecers with the autonomy needed to pursue cultural objectives valued by the minority nation.

A national commitment to recognition must include substantive action, like the provision of group-differentiated rights, if it is to succeed in carving out a place for cultural minorities in the national identity. However, when it comes to Indigenous peoples in Canada, the question has been raised as to whether sufficient recognition can be provided to "modify, let alone transcend, the breadth of power at play in colonial relationships" (Coulthard 2014, 31). The colonial foundation of the Canadian nation-state is argued to manifest in too profound a marginalization of Indigenous peoples to be overcome through a politics of recognition, even one substantiated by concrete action like the provision of group-differentiated rights. Since the source of Indigenous marginalization is woven into the structure of the Canadian nation (Alfred 2009, 13), the reconciliation that enables Indigenous people to see themselves within the larger Canadian nation is thought to be impossible.

Ultimately, whether or not the colonial origin of the Canadian nation is an insurmountable hurdle to Indigenous identification with Canada will be decided by Indigenous people themselves. In principle, Indigenous peoples can imagine themselves as part of a broader Canadian nationality, but whether they choose to depends on whether their cultural aspirations are attainable within the context of that broader nationality. The only arbiter of whether Canada has done enough to enable Indigenous aspirations are Indigenous people themselves, but other Canadians can influence their decision by substantiating their politics of recognition with group-based rights and other measures.

\section{CONCLUSION}


Conceptualizing Canada as a multicultural nation is worthwhile in having the potential to expand the freedom of all involved. Membership in a multicultural Canadian nation expands the positive freedom of the nation's members by developing the broadest possible basis for collective solidarity and action. The horizons of meaning available to individuals are broadened through their participation in the Canadian identity. The cultural heritage of Canadians from other backgrounds becomes part of one's own identity through the mutual link of the shared Canadian nationality. However, these advantages are unavailable to someone whose specific culture receives insufficient recognition to facilitate their identification with the Canadian nation. The provision of sufficient recognition is not merely conceptual but must address inequalities faced by cultural minorities to ensure that they are able to see themselves within the broader multicultural nation. Although we find in the political philosophies of Charles Taylor and Will Kymlicka the theoretical resources to conceive of multicultural nationhood, there remains the considerable task of realizing it in practice.

\section{ACKNOWLEDGEMENTS}

I thank Robert Timko and Elizabeth Trott for their encouragement, suggestions, and comments. I would also like to thank Priya Selvarajoo, Joseph Dattilo, Dallas Jokic, and the anonymous reviewers for their helpful comments on various drafts of the paper.

\section{CREATIVE COMMONS ATTRIBUTION NON-COMMERICAL STATEMENT}

This is an Accepted Manuscript version of a paper published in the American Review of Canadian Studies on October $13^{\text {th }}, 2021$. It is deposited under the terms of the Creative Commons Attribution Non-Commercial License, which permits non-commercial re-use, distribution, and reproduction in any medium, provided the final, published version of the original work is properly cited. 


\section{Notes}

1. I focus here on Taylor's critique of atomistic liberalism in The Pattern of Politics, however he later expanded on this theme in "Atomism" and "What's wrong with negative liberty?"

2. Kymlicka notes that the distinction between national minorities and ethnic groups does not capture all of the diversity in society, and in later writings he includes religious groups, and "sui generis groups" as other categories (Kymlicka \& Norman 2000, 19).

3. For instance, Rorty (1998), Day (2001), Bannerji (2001), Barry (2013), Coulthard (2014).

4. There are other definitions of nation. These include political definitions that define nations as the outgrowth of a certain kind of politics meant to contest or consolidate states (Fanon 1999; Brueilly 1993; Hobsbawm 2012), and discursive definitions that say that nationalism is a discourse people utilize to interpret their experiences (Calhoun 1990; Özkirimli 2005). While these definitions are flawed, there is not space here to discuss where they go astray.

5. Although my focus is on Canadian theories of multiculturalism and the Canadian context, the overall model of multicultural nationhood I present in this article is applicable to other theories of multiculturalism as an ethical stance, like the Bristol School (Levey 2018, 210), and other locales, like Britain. 


\section{References}

Alfred, T. 2009. Peace, Power, Righteousness: An Indigenous Manifesto. Second Edition. Oxford: Oxford University Press.

Anderson, B. 2016. Imagined Communities. Revised Edition. New York: Verso Books.

Bannerji, H. 2001. The Dark Side of the Nation. Toronto: Canadian Scholars Press.

Barry, B. 2013. Culture and Equality: An Egalitarian Critique of Multiculturalism. Hoboken: Wiley Blackwell.

Bibby, R. 1990. Mosaic Madness. Toronto: Stoddart Publishing.

Bickerton, J., S. Brooks, and A-G. Gagnon. 2006. Freedom, Equality, Community: The Political Philosophy of Six Influential Canadians. Montreal: McGill-Queens University Press.

Bissoondath, N. 2002. Selling Illusions. Toronto: Penguin Books.

Bourassa, H. 1969. "French-Canadian Patriotism.” In French-Canadian Nationalism, edited by Ramsey Cook, 118-131. Toronto: Macmillan of Canada.

Breuilly, J. 1993. Nationalism and the State. Manchester: Manchester University Press.

Calhoun, C. 1997. Nationalism. Minneapolis: Open University Press.

Coulthard, G.S. 2014. Red Skin, White Masks: Rejecting the Colonial Politics of Recognition. Minneapolis: University of Minneapolis Press.

Day, R. 2001. “'Who Is This We That Gives The Gift?' Native American Political Theory and the Western Tradition.” Critical Horizons, 2(2): 173-201.

Fanon, Franz. 1991. The Wretched of the Earth. New York: Grove Weidenfeld.

Hobsbawm, E. 1990. Nations and Nationalism Since 1780. Second Edition. Cambridge: Cambridge University Press.

Hobsbawm, E. 2012. “Introduction: Inventing Traditions.” In The Invention of Tradition, edited by Eric Hobsbawm \& Terence Ranger, 1-14. Cambridge: Cambridge University Press.

Kernerman, G. 2005. Multicultural Nationalism. Vancouver: UBC Press.

Kohn, H. 1961. The Idea of Nationalism. New York: The Macmillan Company.

Kymlikca, W. 1989. Liberalism, Community, and Culture. Oxford: Oxford University Press. 
— 1995. Multicultural Citizenship. Oxford: Oxford University Press.

— \& Norman, W.J. 2000. Citizenship in Diverse Societies. Oxford: Oxford University Press.

- 2001. Politics in the Vernacular. Oxford: Oxford University Press.

Levey, G. 2018. “The Bristol School of Multiculturalism.” Ethnicities, 19(1): 200-226.

Morton, W.L. 1962. The Canadian Identity. Toronto: University of Toronto Press.

O’Neill, D. 1999. "Multicultural Liberals and the Rushdie Affair: A Critique of Kymlicka, Taylor, and Walzer." The Review of Politics, 61(2): 219-250.

Özkırıml1, U. 2005. Contemporary Debates on Nationalism. New York: Palgrave Macmillan.

Patten, A. 2014. Equal Recognition. Princeton: Princeton University Press.

Sibley, R. 2008. Northern Spirits. Montreal: McGill-Queens University Press.

Smith, A. 2005. "Ethno-Symbolism and the Study of Nationalism." In Nations and Nationalism: A Reader, edited by Philip Spencer \& Howard Wollman, 23-31. New Brunswick: Rutgers University Press.

Renan, E. 1990. “What Is A Nation?" In Nation and Narration, edited by Homi Bhabha, 8-22. London: Routledge.

Rorty, R. 1998. Achieving Our Country. Cambridge: Harvard University Press.

Taylor, C. 1970. The Pattern of Politics. Toronto: McClelland and Stewart.

— 1975. Hegel. Cambridge: Cambridge University Press.

— 1985a. "Atomism.” In Philosophy and the Human Sciences, edited by Charles Taylor, 187-210. Cambridge: Cambridge University Press.

— 1985b. "What's wrong with negative liberty?" In Philosophy and the Human Sciences, edited by Charles Taylor, 211-229. Cambridge: Cambridge University Press.

— 1985c. "Kant's Theory of Freedom." In Philosophy and the Human Sciences, edited by Charles Taylor, 318-337. Cambridge: Cambridge University Press.

— 1989a. Sources of Self. Cambridge: Harvard University Press.

— 1989b. "Cross-Purposes: The Liberal-Communitarian Debate." In Liberalism and the Moral Life, edited by Nancy Rosenblum, 159-182. Cambridge: Harvard University Press. 
- 1991. The Malaise of Modernity. Concord: House of Anansi.

— 1992. "The Politics of Recognition.” In Multiculturalism, edited by Amy Gutman, 42-91. Princeton: Princeton University Press.

— 1993. Reconciling the Solitudes: Essays on Canadian Federalism and Nationalism, edited by Guy Laforest. Montreal: McGill-Queens University Press.

— 1994. “Can liberalism be communitarian?" Critical Review, 8(2): 257-262.

— 1995. "Nationalismus und Moderne." Transit, (9): 181-186.

— 2007. A Secular Age. Harvard: Harvard University Press. 